Article

\title{
Understanding the Green Technical Capabilities and Barriers to Green Buildings in Developing Countries: A Case Study of Thailand
}

\author{
Wenxin Shen ${ }^{1}$, Wenzhe Tang ${ }^{1, *}$, Atthaset Siripanan ${ }^{1}$, Zhen Lei ${ }^{1}$, Colin F. Duffield ${ }^{2}$ and \\ Felix Kin Peng Hui ${ }^{2}$ D \\ 1 Department of Hydraulic Engineering, State Key Laboratory of Hydroscience and Engineering, Tsinghua \\ University, Beijing 100084, China; cwx14@mails.tsinghua.edu.cn (W.S.); atthasetandrew@gmail.com (A.S.); \\ leizhen765466353@126.com (Z.L.) \\ 2 Department of Infrastructure Engineering, The University of Melbourne, Victoria 3010, Australia; \\ colinfd@unimelb.edu.au (C.F.D.); kin.hui@unimelb.edu.au (F.K.P.H.) \\ * Correspondence: twz@mail.tsinghua.edu.cn; Tel.: +86-10-6279-4324
}

Received: 29 August 2018; Accepted: 4 October 2018; Published: 9 October 2018

\begin{abstract}
Green buildings (GB) have been globally adopted for sustainable development by enhancing the resource efficiency, reducing the operation cost, and improving the building environment for users. However, little research has systematically explored the key issues of GB in developing countries. This study has revealed the green technical capabilities and barriers to GB in Thailand from the perspectives of consultants, architects, and engineers, using a questionnaire survey and a case study. The results show experience in meeting the combined requirements of the Leadership in Energy and Environmental Design (LEED) and the green building rating system that Thailand developed in 2010, Thailand's Rating of Energy and Environmental Sustainability (TREES), and "skilled in energy systems" to be the top two most important green technical capabilities. Barriers to GB mainly arise from financial pressure, technical limitations, and inadequate promotion. "Lack of motivations from owners" and "high initial cost" are ranked as the top two barriers to green building. The results collectively reveal that market demand and technological advancement are fundamental drivers for the GB industry, and the government, economic conditions, education, and corporate social responsibility are the other stimuli for the industry. The findings can help project participants adopt appropriate strategies to boost GB in emerging markets in developing countries. Future policies should focus on increasing market demand, encouraging green technology innovation, and reducing the cost of development and construction of GB.
\end{abstract}

Keywords: green building; green technical capability; sustainability; Thailand's Rating of Energy and Environmental Sustainability (TREES); developing country

\section{Introduction}

Green buildings (GB) have been globally adopted for sustainable development by enhancing resource efficiency, reducing operation cost, and improving the building environment for users [1]. According to the World Green Building Council, a 'green' building is "a building that, in its design, construction, or operation, reduces or eliminates negative impacts, and can create positive impacts on our climate and natural environment." [2]. Green building in developing countries in Asia is especially noteworthy, which is an emerging market with fast development [3]. Thailand is an example of a developing country with fast-growing GB markets. After reaching free trade agreements with different countries, Thailand has started to accelerate the development of the GB industry [4]. One of the rating systems that is widely used to systematically evaluate the performance of GB in Thailand 
is the Leadership in Energy and Environmental Design (LEED), which is one of the leading green building rating systems in the world [5]. Since the first GB project received certification from LEED in 2007, 219 projects have been registered with LEED up until July 2018 [6]. In addition to LEED, Thailand developed its own green building rating system in 2010, called Thailand's Rating of Energy and Environmental Sustainability (TREES), which is based on LEED but tailored to the features of Thailand [7]. The number of green buildings applying for TREES is rising fast, demonstrating TREES' significant role in Thailand's GB industry [8-10].

Various studies demonstrate that the development of green buildings deals with broad factors related to technology, the environment, the economy, society, and management [11-15]. There is no doubt that GB requires high green technical capabilities and that the adoption of advanced green technologies can contribute to ameliorating the sustainability performance of buildings. However, the existence of various green technologies does not necessarily mean that project stakeholders have the corresponding capabilities to effectively master and apply them to practical projects to achieve better performance. Furthermore, most previous studies have only regarded green technical capability as a general factor that affects GB projects rather than considering it as an independent layer for project teams and analyzing it in detail. Given the availability of a large number of useful green technologies and limited resources to deliver the project, it is necessary and essential to further investigate and understand which green technical capability is most critical to deliver successful green building projects.

Despite the vast technologies that are available to promote the development of GB, there are also many barriers and risks (e.g., high initial cost), which lead to slow progress in GB practice and implementation, especially in developing countries. Therefore, understanding the barriers to GB development in a specific country will contribute to better solutions for GB implementation. Additionally, existing studies mainly focus on investigating the GB industry in developed countries and regions [16-20], and little research has explored the above factors on GBs in developing countries.

Therefore, the aim of this study is to systematically investigate the key aspects of the green building industry in Thailand, and provide a sound basis for a deep understanding of the technical issues and the barriers to the industry, thereby helping project stakeholders develop appropriate GB strategies in emerging markets.

\section{Literature Review}

\subsection{Propelling Green Buildings into the Mainstream}

Developing GBs has become a global trend for enhancing sustainability by improving energy efficiency, water efficiency, the use of environmental-friendly materials, and indoor air quality, as well as reducing stress on the natural environment [21,22]. However, due to perceived higher initial costs than conventional projects, green buildings' promotion in markets still faces challenges. High upfront costs may reduce the green building's attraction to the public [2], and then affect the market demand for GB, which is the fundamental driver for developing the GB industry. Propelling GB to a mainstream market requires all of the project stakeholders to continuously improve their competence for delivering affordable and sustainable products to the market.

\subsection{Roles of Project Participants in Green Building}

There are multiple players (e.g., owners, consultants, designers, and contractors) involved in the process of GB project delivery, as shown in Figure 1. Consultants, as representatives of owners, have the responsibility to understand the owners' expectations, determine green building objectives, and program critical project issues [23]. Designers are required to establish cost-effective design details, given the owner's requirements and technical specifications [24]. Contractors are supposed to execute the project by efficiently utilizing various resources [25]. It is essential that these project participants have competent capabilities to fulfill the GB project goals [26]. As interdisciplinary 
interactions in complex GB projects become closer and closer, establishing cooperative relationships among participants to form an integrated project team is also critical [27].

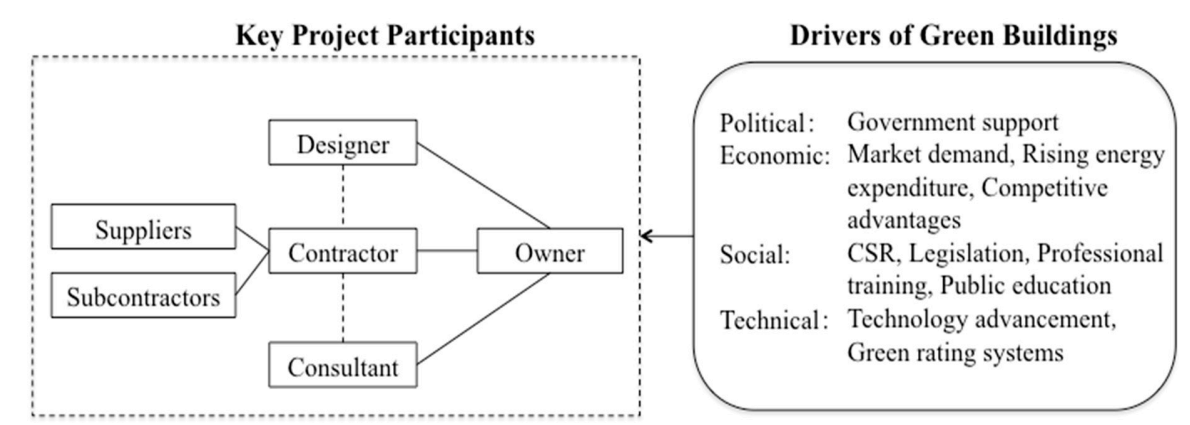

Figure 1. Contractual relationships among key project participants (traditional Design-Bid-Build projects) and main drivers of green buildings.

\subsection{Green Technical Capabilities}

Project stakeholders' performance in GB projects largely relies on their green technical capabilities. Specifically, the dimensions of green technical capability are related to aspects such as energy systems, ventilation, water use, natural light use, landscaping, green roofs and walls, low emitting materials, and waste reduction [1]. Green building rating systems such as LEED and TREES can serve as a guide for incorporating best-in-class green strategies into project implementation, and obtaining certification can raise the profile of industry participants. Thus, experience in meeting requirements and applying the certification of the rating systems are indispensable green technical capabilities [22]. Innovation plays a key role in enhancing project participants' green technical capabilities [28]. For example, project participants' innovative application of energy-efficient measures such as the use of solar thermal technologies, thermal insulation, low-emissivity glass, triple glazing, LED lighting, thermal mass with high ventilation, and reflective coating windows can be effective ways to help buildings reduce their energy consumption [29,30]. Integrating the use of renewable energy sources (e.g., solar) with compatible designs and advanced technologies such as green materials to improve the energy efficiency in heating and cooling is a significant technological innovation direction of green building intensification [31]. Technology advancement is another fundamental driver to green building development.

There are still many barriers, such as higher cost, that prevent project stakeholders from adopting GB technologies and improving their green technical capabilities. Chan et al. identified 21 drivers and 12 promotion strategies for adopting GB technologies in construction [32]. According to their findings, among the promotion strategies for GB technologies adoption, "financial and further market-based incentives", the "availability of better information on cost and benefits of GB technologies", "mandatory governmental policies and regulations", and "green rating and labeling" ranked in the top four.

\subsection{Drivers for Green Buildings}

Delivering GB projects sometimes involves uncertain activities that cause unexpected hidden costs and therefore gain little appreciation among stakeholders in many contexts [33]. The drivers for GB projects have been a hot topic for researchers. The major motivations for GB, which include rising energy expenditure, green rating systems, competitive advantages and legislation, have not significantly changed over time [34]. The research from Windapo also pointed out that the reasons for the increase in GB projects were more associated with economic factors than ecological factors. As shown in Figure 1, in addition to market demand and technology advancement, government support, economic conditions, professional training, public education, and corporate social responsibility are also stimuli for GB. The government can play a supplementary role in promoting GB by promulgating laws and policies on issues such as favorable investment conditions, and sustainable building criteria 
related to energy efficiency, water efficiency, pollution prevention, and the built environment [35]. Research grants and subsidies can be set by the government to encourage academics and practitioners to embrace green technological innovation [2]. The government can also play a role in improving the macro economy, which can increase the investment intention of owners and enhance consumers' purchasing power for GB products [36]. Professional training and public education are important measures to raise industry and public awareness of the long-term economic, environmental, and social value of the green building [37,38]. With the diffusion of the sustainable concept, a desire to demonstrate corporate social responsibility and improve industry image are incentives for owners to invest in GB to lead the market and win long-term payback [39].

\subsection{Critical Success Factors of Green Buildings}

A number of empirical studies have been conducted to identify the critical success factors for GB [16,40-43]. Based on previous research regarding GB in Thailand, critical success factors for GB can be classified under the following categories: the competence of the project participants, integration of project team, technical and management innovation, external environment, and project characteristics [41].

The competence of the project participants refers to the competences of the consultants, contractors, designers, project managers, and project team regarding GB. It is critical that these project participants have the capabilities to implement GB projects [24,25]. For example, GB consultants are responsible for understanding the owners' requirements, conducting investigation and feasibility analysis to determine appropriate plans, and providing professional advice regarding the application of GB standards [22].

Integration of the project team is related to good relationships among participants, communication among participants, the early involvement of key participants, and support from senior decision makers. Complex GB projects require close interdisciplinary interactions among participants [44]. Establishing good relationships among stakeholders can contribute to facilitating information sharing and integrating various resources. Open communication plays an essential role in reducing information asymmetry and enables project participants to understand each other's expectations and requirements, thereby enhancing the competence of the project team for achieving superior performance in GB [43]. Support from senior decision makers, such as by providing money, human capital, and equipment, is also significant for the successful implementation of GB projects [44].

The external environment consists of the economic and sociopolitical environment such as the status of the economy, society's attitude toward green products, and government involvement [41]. These factors can largely determine demand and supply in the GB market, which influences the development of GB [45]. One example is that if the public is aware of the benefits of green buildings in saving energy and environmental protection, and they support the GB projects, the GB projects will be more likely to succeed. The government can also have a critical influence on promoting green building through tax reduction and financial incentives for green technological advancement, and public education [40].

\subsection{Empirical Research Questions}

Although there are many studies that have revealed the status, success factors, and rating systems of GB, the majority focus on developed countries and regions $[15,18,19,21,29]$, and there is a clear need to learn the status of GB in developing countries. Thus, the objectives of this study are to systematically outline the overall picture of the GB industry in Thailand, and provide a sound basis for revealing the drivers of the industry. Understanding the holistic status can help project participants adopt appropriate strategies to successfully promote GB in the emerging markets of developing countries. To achieve this, the relevant themes that need further investigation have been elaborated:

- What is the importance of project participants' green technical capabilities in Thailand?

- What are the barriers to green buildings in Thailand? 
- What are the actual performances of green buildings in terms of cost, time, and quality in Thailand?

\section{Research Methods}

\subsection{Data Collection}

In this research, both quantitative and qualitative data was collected by two approaches, namely a questionnaire survey and a case study. The questionnaire survey was conducted to obtain the quantitative data. The case study was used to validate and interpret the results of the questionnaire survey. The combination of these two methods can provide the researcher with both broad and in-depth perspectives that enable understanding the research questions.

Before the questionnaire survey was constructed, phone interviews were conducted with two professionals who were familiar with LEED and TREES certified projects in Thailand, who both had more than 15 years of experience in the design and construction industry and also had participated in more than three green building projects in Thailand. The main purpose of these interviews is to affirm that the investigative information (green technical capabilities and barriers) in the questionnaire is appropriate to the objectives and green practice. In the light of their valuable advice, some inappropriate information was eliminated.

In the process of the questionnaire survey, first, the design and construction firms that carry out the green building projects were identified and contacted. After getting approval by the companies, the authors directly contacted qualified potential respondents and conducted face-to-face questionnaire surveys or sent the questionnaire by email. Eventually, a total of 70 questionnaires was delivered to architects, engineers, and consultants, who had rich experience in LEED or TREES projects in Thailand.

The questionnaire consisted of three parts of questions. The first part was about the respondents' personal information with respect to their roles of work, professions, and experience involved in GB. The second part was related to the specific GB project that the respondent was most familiar with. The respondents were asked to provide information on this project, such as its location, rating level in the corresponding rating system, type of owners, and delivery method. The following part contained four groups of questions, which arose from the literature review, to estimate: (1) the importance of 14 indicators of green technical capabilities, (2) nine indicators of the barriers to green building, and (3) three indicators of project performance on a five-point Likert scale.

The number of the returned questionnaire is 38 . The response rate is $54.3 \%$, which is acceptable. There were 145 projects and 30 projects in Thailand that had successfully applied for LEED and TREES, respectively $[5,7]$ by the end of June 2018. The profiles of the respondents are shown in Table 1.

Table 1. Profiles of respondents.

\begin{tabular}{cccc}
\hline Category & & Number & Percentage \\
\hline \multirow{3}{*}{ Respondents' profession } & Architect & 16 & 42.2 \\
& Engineer & 11 & 28.9 \\
& Consultant & 11 & 28.9 \\
\hline & Total & 38 & 100.0 \\
\hline \multirow{2}{*}{ Number of green } & 1 project & 6 & 15.8 \\
building projects & 2 projects & 10 & 26.3 \\
involved in & 3 projects & 5 & 13.2 \\
& $>3$ projects & 17 & 44.7 \\
\hline & Total & 38 & 100.0 \\
\hline
\end{tabular}

Given the distribution and demography of the respondents, and the relatively limited number of green building projects in Thailand, the collected data can still largely represent the whole green building industry in Thailand. Out of the 38 completed questionnaires received, $42.2 \%$ of responses came from architects, and $28.9 \%$ came from engineers and consultants, respectively. About $60 \%$ of 
respondents had participated in more than two green building projects, indicating that most of the respondents were experienced professionals in green buildings.

\subsection{Data Analysis Techniques}

The collected data from the questionnaires were analyzed using the Statistical Package for Social Science (SPSS 19.0). The following data analysis techniques were performed: (1) reliability tests, (2) estimations of the sample population mean, (3) rank cases, (4) Spearman rank correlations, and (5) factor analyses.

The reliability and validity of the collected data were evaluated by Cronbach's alpha coefficient [46]. If the Cronbach's alpha range value was between $0.6-0.7$, it can be considered as a sufficient scale; if the value is greater than 0.7 , it can be accepted as indicative of a reliable scale [47]. Spearman rank correlation results are assessed by a significant level, and the general criteria is at a significance level of 0.05 . In order to examine the appropriateness of the data for factor analysis, the Kaiser-Meyer-Olkin (KMO) test and Bartlett's test of sphericity were performed. The criteria of the value of KMO should be greater than 0.5 , and the Bartlett's test of sphericity needs to be significant $(p<0.05)[48]$.

\section{Survey Results}

\subsection{Characteristics of Sample Projects}

The characteristics of 38 sample projects are shown in Table 2. Among the sample projects, 21 projects applied for an LEED certificate, which accounted for $55.3 \%$ of the total amount of projects. The rest of the projects applied for TREES. The majority of projects (33 of 38) were newly constructed commercial buildings. Most of the cases were implemented by the Design-Bid-Build project delivery approach (81.6\%). In terms of GB certification level, $36.8 \%$ of the sample projects received certified levels and gold levels, respectively, followed by platinum levels (21.1\%) and silver levels (5.3\%).

Table 2. Characteristics of Sample Projects. GB: green buildings, LEED: Leadership in Energy and Environmental Design, TREES: Thailand's Rating of Energy and Environmental Sustainability.

\begin{tabular}{|c|c|c|c|}
\hline & Category & Frequency & Percentage \\
\hline \multirow[t]{3}{*}{ Types of rating systems } & LEED Project & 21 & 55.3 \\
\hline & TREES Project & 17 & 44.7 \\
\hline & Total & 38 & 100.0 \\
\hline \multirow{3}{*}{ Project categories } & New construction & 33 & 86.8 \\
\hline & Renovation & 5 & 13.2 \\
\hline & Total & 38 & 100.0 \\
\hline \multirow[t]{4}{*}{ Building types } & Commercial & 28 & 73.7 \\
\hline & Educational & 5 & 13.2 \\
\hline & Residential & 5 & 13.2 \\
\hline & Total & 38 & 100.0 \\
\hline \multirow[t]{3}{*}{ Owner types } & Private sector & 28 & 73.7 \\
\hline & Public sector & 10 & 26.3 \\
\hline & Total & 38 & 100.0 \\
\hline \multirow[t]{3}{*}{ Delivery methods } & Design-bid-build & 31 & 81.6 \\
\hline & Design-build & 7 & 18.4 \\
\hline & Total & 38 & 100.0 \\
\hline \multirow[t]{5}{*}{ Contract types } & Lump sum & 21 & 55.3 \\
\hline & Percentage of construction fee & 7 & 18.4 \\
\hline & Unit price & 8 & 21.1 \\
\hline & N/A & 2 & 5.3 \\
\hline & Total & 38 & 100.0 \\
\hline \multirow[t]{5}{*}{ GB Certification levels } & Certified & 14 & 36.8 \\
\hline & Silver & 2 & 5.3 \\
\hline & Gold & 14 & 36.8 \\
\hline & Platinum & 8 & 21.1 \\
\hline & Total & 38 & 100.0 \\
\hline
\end{tabular}




\subsection{Green Technical Capabilities}

The respondents were asked to rate the importance of the identified technical capabilities related to green building on a five-point scale ranging from " $1=$ not important" to " $5=$ very important". The results are presented in Table 3.

Table 3. Importance of green technical capabilities.

\begin{tabular}{|c|c|c|c|c|c|c|c|c|}
\hline \multirow[t]{2}{*}{ Green Technical Capabilities } & \multicolumn{2}{|c|}{ Overall } & \multicolumn{2}{|c|}{$\begin{array}{c}\text { GB } \\
\text { Consultant }\end{array}$} & \multicolumn{2}{|c|}{ Architect } & \multicolumn{2}{|c|}{ Engineer } \\
\hline & M. & R. & M. & R. & M. & R. & M. & $\mathbf{R}$. \\
\hline Experienced in meeting requirements of LEED/TREES & 4.55 & 1 & 4.73 & 1 & 4.31 & 2 & 4.73 & 1 \\
\hline Skilled in energy systems & 4.42 & 2 & 4.64 & 3 & 4.44 & 1 & 4.18 & 4 \\
\hline Experienced in applying certification of LEED/TREES & 4.37 & 3 & 4.73 & 1 & 4.31 & 2 & 4.09 & 6 \\
\hline Skilled in using ventilation methods & 4.29 & 4 & 4.45 & 4 & 4.13 & 4 & 4.36 & 2 \\
\hline Skilled in using natural light methods & 4.13 & 5 & 4.36 & 5 & 4 & 6 & 4.09 & 6 \\
\hline Skilled in using low-emitting materials & 4.13 & 5 & 4.09 & 10 & 4.06 & 5 & 4.27 & 3 \\
\hline Skilled in water use & 4.11 & 7 & 4.27 & 7 & 4.00 & 6 & 4.09 & 6 \\
\hline Skilled in low environmental impact techniques & 4.05 & 8 & 4.27 & 7 & 3.94 & 9 & 4.00 & 10 \\
\hline Skilled in pollution prevention and waste reduction & 4.05 & 8 & 4.36 & 5 & 3.94 & 9 & 3.91 & 11 \\
\hline Skilled in landscaping & 4.05 & 8 & 4.27 & 7 & 4.00 & 6 & 3.91 & 11 \\
\hline Skilled in using renewable energy & 3.97 & 11 & 4.00 & 11 & 3.88 & 11 & 4.09 & 6 \\
\hline Skilled in using green roof and wall & 3.87 & 12 & 3.64 & 13 & 3.81 & 12 & 4.18 & 4 \\
\hline Skilled in using recycled materials & 3.84 & 13 & 3.91 & 12 & 3.75 & 13 & 3.91 & 11 \\
\hline Innovation in using materials & 3.68 & 14 & 3.64 & 13 & 3.63 & 14 & 3.82 & 14 \\
\hline Average & 4.11 & - & 4.24 & - & 4.01 & - & 4.12 & - \\
\hline
\end{tabular}

Note: M. = mean; R. = rank; Cronbach's alpha $=0.933$.

Referring to Table 3, "experienced in LEED/TREES rating systems" ranked first, and "experienced in applying certification of LEED/TREES" also had a high rank of the third. These show that understanding and meeting the requirements of LEED/TREES rating systems are critical capabilities for project participants to achieve the goals of green building. All of the ratings were higher than 3.6, and the average score of the green technical capabilities was 4.11 , showing that all of the specific green technical capabilities were important in the delivery of green building projects.

To test whether there is a consensus among the groups of consultants, architects, and engineers on the rankings of the importance of green technical capabilities, the Spearman rank correlation coefficient has been calculated (see Table 4).

Table 4. Correlation among participants on green technical capabilities.

\begin{tabular}{cccc}
\hline & Consultant & Architect & Engineer \\
\hline \multirow{2}{*}{ Consultant } & 1 & - & - \\
& - & - & - \\
\hline \multirow{2}{*}{ Architect } & $0.626^{* *}$ & 1 & - \\
& 0.000 & - & 1 \\
\multirow{2}{*}{ Engineer } & 0.434 & $0.665^{* *}$ & - \\
\hline
\end{tabular}

Note: ${ }^{* *}=$ correlation is significant at the 0.01 level (two-tailed).

As shown in Table 4, the architects' ranking had a significant agreement with the rankings of consultants and engineers, respectively $(r=0.873$ and 0.665 , respectively, $p<0.01)$. This may be because architects' jobs are closely tied with the other two groups. In general, architects' works are the successor activities of the consultants, and the predecessor activities of the engineers. However, there are no statistically correlated relationships between the rankings of consultants and engineers. 


\subsection{Barriers to Green Building}

To learn the status of barriers to green building in Thailand, respondents were asked to rate the relevant indicators on a five-point scale ranging from " $1=$ strongly disagree" to " $5=$ strongly agree". The results are presented in Table 5.

Table 5. Ranking of barriers to green buildings.

\begin{tabular}{ccccccccc}
\hline Barriers & \multicolumn{2}{c}{ Overall } & \multicolumn{2}{c}{$\begin{array}{c}\text { GB } \\
\text { Consultant }\end{array}$} & \multicolumn{2}{c}{ Architect } & \multicolumn{2}{c}{ Engineer } \\
\hline & M. & R. & M. & R. & M. & R. & M. & R. \\
\hline Lack of motivations from owners & 4.39 & 1 & 4.45 & 2 & 4.38 & 1 & 4.36 & 1 \\
\hline High initial cost & 4.21 & 2 & 4.27 & 3 & 4.06 & 3 & 4.36 & 1 \\
\hline Lack of government support & 4.21 & 2 & 4.55 & 1 & 4.25 & 2 & 3.82 & 4 \\
\hline $\begin{array}{c}\text { The high expense of preparing documents for } \\
\text { LEED/TREES certification }\end{array}$ & 3.92 & 4 & 4.09 & 5 & 3.75 & 5 & 4.00 & 3 \\
\hline Lack of training and education in the industry & 3.82 & 5 & 4.18 & 4 & 3.81 & 4 & 3.45 & 6 \\
\hline Long payback period & 3.79 & 6 & 3.91 & 6 & 3.69 & 6 & 3.82 & 4 \\
\hline Lack of green technologies & 3.24 & 7 & 3.18 & 7 & 3.38 & 8 & 3.09 & 7 \\
\hline Lack of green products suppliers & 3.21 & 8 & 3.18 & 7 & 3.44 & 7 & 2.91 & 9 \\
\hline Lack of skilled workers & 3.11 & 9 & 3.00 & 9 & 3.25 & 9 & 3.00 & 8 \\
\hline Average & 3.77 & - & 3.87 & - & 3.78 & - & 3.65 & - \\
\hline
\end{tabular}

Note: $\mathrm{M} .=$ mean; $\mathrm{R} .=$ rank. Cronbach's alpha $=0.721$.

As seen in Table 5 and Figure 2, "lack of motivations from owners" and "high initial cost" are ranked as the first and the second barriers to GB, respectively, showing that financial pressure is the main concern of the owners. The results also demonstrate that a lack of government support, the high expense of preparing LEED/TREES documentation, and the lack of training and education in the industry are also the key barriers to GB in Thailand.

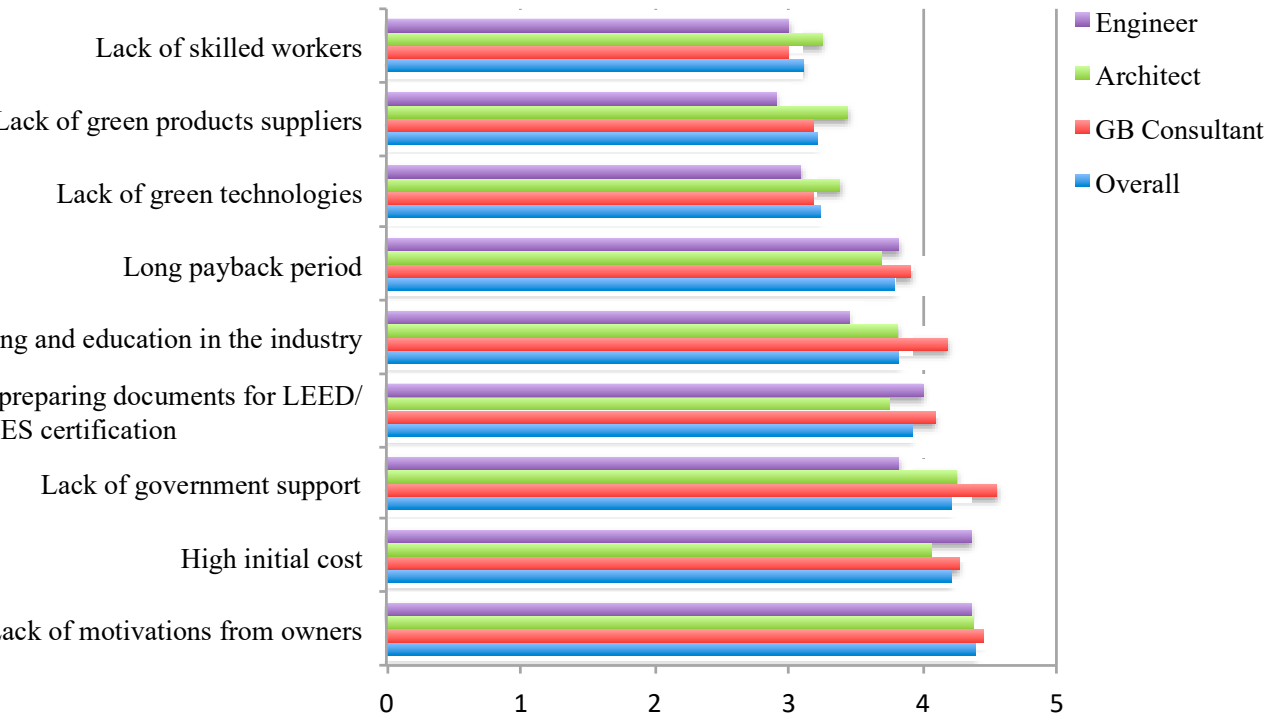

Figure 2. Barriers to green buildings.

To test whether there is a consensus among the groups of consultants, architects, and engineers on the barriers to GB, the Spearman rank correlation coefficient has been calculated. Referring to Table 6, the correlation coefficients are all above $0.760(p<0.05)$, indicating that these three groups have a significant agreement with the ranking of barriers to GB. 
Table 6. Correlation among participants on green building barriers.

\begin{tabular}{cccc}
\hline & Consultant & Architect & Engineer \\
\hline \multirow{2}{*}{ Consultant } & 1 & - & - \\
& - & - & - \\
\hline \multirow{2}{*}{ Architect } & $0.979^{* *}$ & 1 & - \\
& 0.000 & - & 1 \\
\multirow{2}{*}{ Engineer } & $0.760^{*}$ & $0.790^{*}$ & -
\end{tabular}

Note: ${ }^{*}=$ Correlation is significant at the 0.05 level (two-tailed); ${ }^{* *}=$ Correlation is significant at the 0.01 level (two-tailed).

\subsection{Green Building Performance}

To learn the ultimate GB performance in Thailand, respondents were asked to rate the performances of quality, schedule, and cost on a five-point scale ranging from " $1=$ very low" to " 5 = very high". The results are presented in Table 7.

Table 7. Green building performances.

\begin{tabular}{ccccccccc}
\hline \multirow{2}{*}{ Performances } & \multicolumn{2}{c}{ Overall } & \multicolumn{2}{c}{ GB Consultant } & \multicolumn{2}{c}{ Architect } & \multicolumn{2}{c}{ Engineer } \\
\cline { 2 - 9 } & M. & R. & M. & R. & M. & R. & M. & R. \\
\hline Quality & 4.26 & 1 & 4.55 & 1 & 4.13 & 1 & 4.18 & 1 \\
Schedule & 3.79 & 2 & 4.00 & 2 & 3.75 & 2 & 3.64 & 2 \\
Cost & 3.24 & 3 & 3.36 & 3 & 3.43 & 3 & 2.82 & 3 \\
Total & 3.76 & - & 3.97 & - & 3.77 & - & 3.54 & - \\
\hline
\end{tabular}

Note: $\mathrm{M} .=$ mean; $\mathrm{R} .=$ rank. Cronbach's alpha $=0.607$.

The results show that the overall rating of green building performances is 3.76, suggesting that there is room for the project participants to improve green building project delivery in Thailand. Specifically, the cost performance is rated the lowest, showing the difficulty in green building cost management.

\section{Data Analysis and Discussion}

\subsection{Factor Analysis of Green Technical Capabilities}

To unearth the underlying patterns of green technical capabilities, reducing the dimensionality of the items in Table 3 is imperative [49]. Therefore, factor analysis was conducted on the green technical capabilities of participants, with the results presented in Table 8. The KMO value of the green technical capabilities was $0.845(p<0.05)$, implying the appropriateness of factor analysis. Three underlying components are extracted, and these components cumulatively explain $74.4 \%$ of the total variance. These three components are discussed below.

\subsubsection{Technical Skills in Green Building}

Technical skills in green building involve energy systems, ventilation, water use, pollution prevention, waste reduction, natural light use, landscaping, and low environmental impact techniques. "Skilled in energy systems" is ranked as the second most important green technical capability (see Table 5), which is attributed to the buildings consuming a large share of energy. Project participants should be good at not only energy-efficiency techniques (such as whole building energy simulation, cooling, and heating applications), but also optimally combining these techniques with compatible building design and materials (e.g., the use of natural light and solar heating). "Skilled in using ventilation methods" is ranked as the fourth most important green technical skill (see Table 5), which can help improve indoor air quality and reduce energy consumption by using technologies such as 
natural ventilation. Although Thailand is not water-deficient, the respondents still consider "skilled in water use" to be important for green building, especially on indoor water use reduction. It is also important that participants are capable of reducing the negative externalities of buildings at both the construction and operation stages by applying low environmental impact techniques. Landscapes with the green feature can not only improve the attractiveness of the communities in which the buildings are located, they also play roles in reducing water use in irrigation and protecting the natural environment.

Table 8. Factor profile of green technical capabilities.

\begin{tabular}{|c|c|c|c|}
\hline Factor Structure & Factor Loading & Variance Explained & Cronbach's Alphas \\
\hline Technical skills in green building & & $33.82 \%$ & 0.933 \\
\hline Skilled in pollution prevention and waste reduction & 0.871 & & \\
\hline Skilled in low environmental impact techniques & 0.854 & & \\
\hline Skilled in water use & 0.818 & & \\
\hline Skilled in energy systems & 0.776 & & \\
\hline Skilled in using natural light methods & 0.767 & & \\
\hline Skilled in using ventilation methods & 0.620 & & \\
\hline Skilled in landscaping & 0.568 & & \\
\hline Use of green materials & & $28.98 \%$ & 0.911 \\
\hline Innovation in using materials & 0.842 & & \\
\hline Skilled in using low emitting materials & 0.809 & & \\
\hline Skilled in using green roof and wall & 0.798 & & \\
\hline Skilled in using recycled materials & 0.758 & & \\
\hline Skilled in using renewable energy & 0.709 & & \\
\hline Familiarity with green building rating systems & & $11.65 \%$ & 0.586 \\
\hline Experienced in meeting requirements of LEED/TREES & 0.837 & & \\
\hline Experienced in applying certification of LEED/TREES & 0.815 & & \\
\hline
\end{tabular}

\subsubsection{Use of Green Materials}

The use of green materials is related to pollution reduction and energy efficiency. As many building materials create toxic emissions such as carcinogens, irritants, and odors [15], project participants who are skilled in using low-emitting materials can largely avoid indoor air pollution, which is critical to users' health. Due to construction being intensively resource-consuming, designers' applying environmentally friendly materials (e.g., recycled materials) to green buildings can effectively help reduce human activities' pressure on the natural environment and avoid damage to natural resources such as forests and minerals, thereby decreasing greenhouse gas emissions [50]. The use of green roofs and walls is closely related to the utilization of renewable energy, especially solar power. Both architects and engineers can play an important role in integrating green roof and walls with using solar energy. For example, solar water heater/solar PV can be parts of roofs, and optimized building structures combining with thermal insulation materials can enable solar radiation heat and daylight to be efficiently received. It is necessary for project participants to continuously encourage innovation in green materials in order to reduce costs during the construction, operation, and maintenance stages.

\subsubsection{Familiarity with Green Building Rating Systems}

Familiarity with the green building rating systems includes "experience in meeting the requirements of LEED/TREES" and "experience in applying certification of LEED/TREES". These two green technical capabilities are ranked as first and third most important, showing the criticality for project participants to be good at LEED/TREES in delivering green buildings. LEED and TREES are recognized as effective green building assessment tools in Thailand. More than half (55.3\%) of the investigated cases used LEED as their green building rating systems, showing that LEED is popular in Thailand (see Table 2). This might be because application for the LEED can not only improve the value of the green buildings, it can also raise the international profiles of investors. Considering that TREES were founded in 2010, $44.7 \%$ of the surveyed cases applied TREES, demonstrating that the native rating system incorporating local features has also diffused well within the green building industry of Thailand. 


\subsection{Factor Analysis of Barriers to Green Building}

Factor analysis was conducted on the barriers to green building, with the results presented in Table 9. The KMO value of the green technical capabilities is $0.612(p<0.05)$, indicating that the data were suitable for factor analysis.

Table 9. Factor profile of green technical capabilities.

\begin{tabular}{cccc}
\hline Factor Structure & Factor Loading & Variance Explained & Cronbach's Alphas \\
\hline Technical limitation & & $22.46 \%$ & 0.707 \\
Lack of green product supplier & 0.791 & & \\
Lack of skilled workers & 0.785 & & 0.674 \\
Lack of green technologies & 0.712 & & \\
$\quad$ Financial pressure & & & \\
Long payback period & 0.841 & & \\
High initial cost & 0.732 & & 0.548 \\
certification & 0.698 & & \\
Inadequate promotion & & & \\
Lack of government support & 0.778 & & \\
Lagh expense of preparing documents for LEED/TREES & 0.662 & & \\
Lack of motivations from owners & 0.649 & & \\
\hline
\end{tabular}

\subsubsection{Technical Limitation}

Technical limitations include a "lack of green product suppliers", "lack [of] skilled workers", and "lack of green technologies". As Thailand is a developing country, its green building market is still immature. This leads to that some LEED/TREES-approved green technologies and products being unavailable in the locality. Correspondingly, the shortage of skilled workers is also a barrier to the development of green buildings. The results are in line with the findings from the case studies in Turkey [39].

\subsubsection{Financial Pressure}

Financial pressure includes a "long payback period", "high initial cost", and "high expense of preparing documents for LEED/TREES certification". High initial cost is ranked as the second (tied) major barrier to green building (see Table 5). This can be explained by the survey results of project performance (see Table 7), in which the cost performance is the lowest (score $=3.24$ ) compared with quality performance (score $=4.26$ ) and schedule performance (score $=3.79$ ). Specifically, nine of 38 surveyed cases have very poor cost performance, showing that cost control is the major difficulty encountered by the project teams during project delivery. Due to the high upfront investment and uncertainty in cost control, it is not surprising to hear the owners' concerns about a long payback period in developing GB projects. Compared to conventional projects, applying LEED/TREES certification incurs extra costs in preparing complex documents and hiring LEED/TREES consultants, which can also be an obstacle to GB.

\subsubsection{Inadequate Promotion}

Inadequate promotion contains a "lack of government support", "lack of training and education in the industry", and "lack of motivations from owners". "Lack of motivations from owners" is ranked as the first barrier to GB (see Table 5), which is largely attributed to the high financial pressure on investment as mentioned above. "Lack of government support" is ranked as the second (tied) barrier (see Table 5), showing that the government's support such as promulgating relevant laws and policies, and providing financial incentives are critical in promoting GB. There are varying regulatory approaches employed by lawmakers and different levels of government (e.g., federal, state, county, and local) to develop green buildings, which can be categorized into three approaches [51]. The first one is to require all public construction projects to meet certain green criteria such as LEED. These laws, and their corresponding public projects, help to raise awareness of sustainable design practices 
and showcase the benefits of green buildings, especially to the private sector builders. The second approach is to create incentives for privately developed green projects, such as providing tax credits to developers and consumers, and accelerated permits for developers. Authorizing expedited permitting for GB can particularly appeal to developers who have been overburdened by time-consuming and cumbersome permitting processes. The final, and most striking method of regulations, is to require that all new construction projects over a certain square footage, both private and public, meet certain green standards. Such laws have been enacted in several major cities such as Boston and Los Angeles. Thailand also has embraced this method to spur large-scale green development. In July 2017, the Department of Alternative Energy Development and Efficiency ("DEDE") has launched Thailand's first compulsory building energy consumption standards, namely the Green Building Energy Code ("GBEC") [52]. The GBEC established certain standards and specifications related to the building envelope, electrical lighting system, air conditioning system, water heating, overall energy consumption, and renewable energy outfitting within the building, which all of the large buildings' design and construction must follow [52]. It is estimated that 74 million units of electricity would be reduced if stricter standards were applied to energy consumption in larger buildings in Thailand [53].

As the green building development is still in its early stages in Thailand, training and education in the industry have much room to improve. Both professional training and public education are essential to make the whole society realize the long-term economic, environmental, and social value of GB. Previous studies $[52,53]$ has shown that social influence or social norms can significantly affect people's behaviors in energy use, suggesting that normative-based intervention can be an effective way to educate the public to change their attitude toward green buildings and their behaviors in energy consumption. For example, sending the occupants automated non-invasive personalized normative feedback and educational messages on their energy use and comparing it with the energy consumption in a green building could be plausible to help them realize the long-term benefit of GB in saving energy and protecting the environment.

\section{Case Study}

Siam Cement Group's (SCG) 100th Year Building has been praised as the exemplary green building project in Thailand and has been awarded LEED Platinum Certification in 2014, which is the highest LEED achievement [54]. This project is located in Bangkok and consisted of a 37,000 $\mathrm{m}^{2}$ office building and a $38,000 \mathrm{~m}^{2}$ multipurpose building to provide office space for about 1700 employees and make the city greener [55].

The chairman of the SCG Sustainable Development Committee explained the key drivers for their green development. The first driver is to develop a sustainable building that can better respond to the global climate change. The second driver is that developing a green building can reflect the company's commitment to social responsibility and sustainable development, which is helpful to develop a larger business network for a greener future. The third reason is that SCG would like to set an example for Thai society showing that green practices are actually affordable and can be implemented in a way that benefits the environment and the ecosystem, and thereby encourage more Thai companies to participate in green development. In order to better commit to sustainable growth, the SCG Green Solution committee was formed and included five experts certified by the United States (US) Green Building Council, who are responsible for providing advice on developing green building.

This indicates that the adoption of innovative technologies in GB projects can be influenced by the interaction among different stakeholders [50]. In the process of GB projects, the power of different stakeholders over decisions is dynamically changing in different phases [56]. For example, at the planning stage, the owner has the biggest influence on deciding whether a GB project should be developed and the goals of the green buildings. At the design stage, the architects/engineers are responsible for fulfilling the owner's requirements and have considerable power on the adoption of new technologies. However, a consultant has a low power compared to the main architect. 
A management executive of this project stated that this project emphasized the balance between the needs of society, the environment, and the economy [57]. Since Thailand is a tropical country, it is critical for developers to incorporate their designs into the environment. In this project, many green technologies were adopted to improve the efficiency of the energy and water consumption, reduce employees' commuting time, and create a hygienic environment for all [58]. For example, compared to similar buildings with the same size, the toilets and bathroom fittings in the SCG building were supposed to save $70 \%$ on water consumption, or about six million liters every year. In addition, recycled and environmental-friendly materials (such as low VOCs (volatile organic compounds) emitting materials) have also been incorporated along with careful construction planning and waste management. The designers of the building used energy-efficient LED light bulbs and the tiles that were produced with $60 \%$ recycled materials. The solar panels have a rated generation capacity of 99,000 kW. The glass used in the windows is double-glazed, which can help block sunlight and heat.

Improving the satisfaction of employees or the building users is another essential focus of sustainability. In the designing process, special attention has been paid to the design for the health of employees and the construction of an eco-friendly building. For example, the entrances of offices are equipped with dust-trapping carpets in order to improve the indoor air quality and prevent the proliferation of dust and diseases. There is a large fitness room and a jogging track in the buildings [58].

This case validates the findings of the questionnaire survey that the motivation of the owners is one of the most important determinants for the success of GB projects. This case is also in line with the findings that practitioners of green buildings in Thailand emphasized the skills in energy systems, using ventilation methods and low-emitting materials.

\section{Conclusions and Implications}

The question of how to balance economic development and environmental quality while also improving social welfare and achieving sustainable development is a common challenge faced by developing countries. Clearly, green buildings will become more and more mainstream in the future because of its advantages such as reducing greenhouse gas emissions and energy assumptions, especially in developing countries where environment pollution has become a serious problem. However, the questions of what are the most important green technical capabilities and what are the biggest barriers to implement GB in the developing countries such as Thailand is still unclear. Thus, this study aims to systematically reveal the status of the GB industry in terms of the use of green technologies and the barriers to GB in Thailand, from the perspectives of consultants, architects, and engineers. The major findings are as below.

The analysis of green technical capabilities shows that project participants should emphasize improving their technical skills in green building, the use of green materials, and familiarity with the green building rating systems. Specifically, project participants should be good at not only energy-efficiency techniques (such as whole building energy simulation, and cooling and heating applications), but also optimally combining these techniques with compatible building designs and materials (e.g., the use of natural light and solar heating). The results confirm that understanding and meeting the requirements of LEED/TREES rating systems are essential capabilities for project participants to achieve the goals of green building.

Barriers to green building mainly arise from financial pressures, technical limitations, and inadequate promotion. "Lack of motivations from owners" and "high initial cost" are ranked as the top two barriers to green building, which are in line with the lowest rating on cost performance. In addition to financial pressure, the unavailability of LEED/TREES-approved green technologies, products, and skilled workers in the locality is also an obstacle, which is attributable to green building development still being in its early stages in Thailand. "Lack of government support" is ranked as the second (tied) barrier, showing the government's importance in promoting green building. The government can boost green building by promulgating sustainable building criteria, providing favorable investment 
conditions, setting research grants and subsidies for green technical innovation, directly investing in green building projects, and supporting professional training and public education.

The above insights contribute to the body of knowledge regarding both theoretical and practical perspectives. Firstly, this study identifies and empirically investigates the green technical capabilities and barriers to GB in Thailand, which have not received much attention in previous research. This study highlights the key issues regarding the green building industry in Thailand, which helps practitioners learn the status of the green technical capabilities, project performances, and barriers to GB in a systematical manner. The results show the similarities and differences between GB in Thailand and other developed countries. For example, project practitioners from Thailand perceived "experience in meeting requirements of LEED/TREES", "skill in energy systems", and "experience in applying certification of LEED/TREES" as the top three most important green technical capabilities, while those from Greece considered "renewable energy", "toxic reduction", and "indoor air pollution" to be the top three most important green technologies [15]. This indicates that project participants in Thailand may attach more importance to obtaining the certification of the rating systems while project practitioners from Greece focus more on improving the environment. Secondly, the results collectively reveal that the market demand and technology advancement are the fundamental drivers to the GB industry, and the government, economic conditions, education, and corporate social responsibility are other stimuli to the industry. The findings from this research can be extendable to other developing countries and provide a valuable research and practical reference, especially for project practitioners and policymakers to make appropriate strategies to achieve better GB performance. Specifically, future policy emphasis should focus on investing the needed resources into stimulating the market and supporting the technology advancement, which are one of the most effective methods of improving GB infrastructure. Thirdly, regarding the green technical skills, the findings suggest that project participants should make efforts to improve their knowledge and skills in the use of energy, ventilation methods, natural light methods, and low-emitting materials. Fourthly, this study provides quantitatively empirical evidence for all of the stakeholders to adopt appropriate strategies in promoting green buildings in the emerging markets of developing countries.

\section{Limitations and Future Research Directions}

The findings of this research provide a new perspective to understand GB in Thailand. However, several limitations should be acknowledged. First, although this study used samples from diverse project locations, project types, delivery methods, and project stakeholders to reflect the status of GB industry in Thailand, the sample size is still relatively small. More research efforts are suggested to collect more data to reconfirm the results. Second, the insights of this research are developed on the theories and practical experiences that are available worldwide via the literature, which appears to be extendable to other regions where GB is emerging, especially in developing countries. However, different countries may have various conditions to develop GB, such as the special regulations and policies to support GB, which is worth further investigating in future studies. Third, this study only investigates some of the key aspects of GB from the perspectives of consultants, architects, and engineers in Thailand. One aspect of GB that the paper did not explore was the occupant evaluations of green buildings, which can be a valuable angle to deeply understand the obstacles of GB. Future studies can be conducted to investigate the perceptions of building occupants, owners, and governments. Furthermore, it would be interesting to further investigate the innovations in integrated green technologies, especially on combining energy-efficiency techniques with building designs and the use of green materials.

Author Contributions: W.S. developed the concept, analyzed data, and drafted the paper. W.T. developed the concept and supervised this research. A.S. designed the questionnaire and collected the data. Z.L. assisted in data analysis. C.F.D. and F.K.P.H. reviewed the manuscript and provided valuable comments for revising the manuscript. All the authors read carefully and approved the final version of the manuscript. 
Funding: This research was funded by the National Natural Science Foundation of China (Grant No. 51579135, No. 51379104), State Key Laboratory of Hydroscience and Engineering (Grant No. 2013-KY-5, No. 2015-KY-5), and Major Science and Technology Research Project of Power China (Grant No. DJ-ZDZX-2015-01-02, No. DJ-ZDZX-2015-01-07).

Acknowledgments: The authors would like to thank the questionnaire respondents for their generous support during the survey.

Conflicts of Interest: The authors declare no conflict of interest.

\section{References}

1. Zuo, J.; Zhao, Z.Y. Green building research-current status and future agenda: A review. Renew. Sustain. Energy Rev. 2014, 30, 271-281. [CrossRef]

2. World Green Building Council (WGBC). What Is Green Building? 2018. Available online: http://www. worldgbc.org/what-green-building (accessed on 30 September 2018).

3. Chan, E.H.; Qian, Q.K.; Lam, P.T. The market for green building in developed Asian cities-The perspectives of building designers. Energy Policy 2009, 37, 3061-3070. [CrossRef]

4. Wethyavivorn, P.; Charoenngam, C.; Teerajetgul, W. Strategic Assets Driving Organizational Capabilities of Thai Construction Firms. J. Constr. Eng. Manag. 2009, 135, 1222-1231. [CrossRef]

5. Wu, P.; Song, Y.; Wang, J.; Wang, X.; Zhao, X.; He, Q. Regional variations of credits obtained by LEED 2009 Certified green buildings-A country level analysis. Sustainability 2017, 10, 20. [CrossRef]

6. USGBC. Directory of Projects. 2018. Available online: http://www.usgbc.org/projects/new-construction (accessed on 6 July 2018).

7. Srimalee, S. Innovative Design Trend Result in Sustainable Structure; More Focus on Eco-Friendly Construction Products. The Nation. 2014. Available online: http:/ /www.nationmultimedia.com/business / Architects-lead-green-revolution-30239366.html (accessed on 6 August 2015).

8. Thai Green Building Institute (TGBI). 2018. Available online: http:/ /www.tgbi.or.th/project (accessed on 6 June 2018).

9. Varodompun, J. News-TGBI-Green Building 2012 in Thailand. 2012. Available online: http://www. futurarc.com/index.cfm/events-news/news/2012/news-tgbi-green-building-2012-in-thailand/ (accessed on 3 August 2015).

10. Amnatcharoenrit, B. Thai Businesses Seeing Virtues of Green Buildings. The Nation. 2013. Available online: http:/ / www.nationmultimedia.com/business/Thai-businesses-seeing-virtues-of-green-buildings30206464.html (accessed on 6 August 2015).

11. Love, P.; Niedzweicki, M.; Bullen, P.; Edwards, D. Achieving the Green Building Council of Australia's World Leadership Rating in an Office Building in Perth. J. Constr. Eng. Manag. 2013, 138, 651-660. [CrossRef]

12. Robichaud, L.B.; Anantatmula, V.S. Greening Project Management Practices for Sustainable Construction. J. Manag. Eng. 2011, 27, 48-57. [CrossRef]

13. Enache-Pommer, E.; Horman, M. Key processes in the building delivery of green hospitals. In Proceedings of the Construction Research Congress 2009: Building a Sustainable Future, Seattle, WA, USA, 5-7 April 2009; ASCE: Reston, VA, USA, 2009; pp. 636-645.

14. Riley, D.; Magent, C.; Horman, M. Sustainable metrics: A design process model for high performance buildings. In Proceedings of the CIB World Building Congress, Toronto, ON, Canada, 2-7 May 2004; CIB: Delft, The Netherlands, 2004.

15. Imada, S.J. An Environmental Management Plan for the Construction of Green Buildings. Master's Thesis, University of Calgary, Calgary, AB, Canada, 2002.

16. Vatalis, K.I.; Manoliadis, O.; Charalampides, G.; Platias, S.; Savvidis, S. Sustainability Components Affecting Decisions for Green Building Projects. Procedia Econ. Financ. 2013, 5, 747-756. [CrossRef]

17. Hwang, B.; Lim, E. Critical success factors for key project players and objectives: Case study of Singapore. J. Constr. Eng. Manag. 2013, 139, 204-215. [CrossRef]

18. Hwang, B.-G.; Ng, W.J. Project management knowledge and skills for green construction: Overcoming challenges. Int. J. Proj. Manag. 2013, 31, 272-284. [CrossRef]

19. Swarup, L.; Korkmaz, S.; Riley, D. Project Delivery Metrics for Sustainable, High-Performance Buildings. J. Constr. Eng. Manag. 2011, 137, 1043-1051. [CrossRef] 
20. Korkmaz, S.; Riley, D.; Horman, M. Piloting evaluation metrics for sustainable, high performance building project delivery. J. Constr. Eng. Manag. 2010, 136, 877-885. [CrossRef]

21. Lapinski, A.; Horman, M.; Riley, D. Lean processes for sustainable project delivery. J. Constr. Eng. Manag. 2006, 132, 1083-1091. [CrossRef]

22. Zhao, J.; Lam, K.P. Influential factors analysis on LEED building markets in U.S. East Coast cities by using Support Vector Regression. Sustain. Cities Soc. 2012, 5, 37-41. [CrossRef]

23. Bayraktar, M.; Owens, C. LEED Implementation Guide for Construction Practitioners. J. Archit. Eng. 2010, 16, 85-93. [CrossRef]

24. Chan, A.P.C.; Scott, D.; Chan, A.P.L. Factors affecting the success of a construction project. J. Constr. Eng. Manag. 2004, 130, 153-155. [CrossRef]

25. Inayat, A.; Melhem, H.; Asce, F.; Esmaeily, A.; Asce, M. Critical Success Factors in an Agency Construction Management Environment. J. Constr. Eng. Manag. 2015, 1-7. [CrossRef]

26. Isik, Z.; Arditi, D.; Dikmen, I.; Birgonul, M.T. Impact of corporate strengths/weaknesses on project management competencies. Int. J. Proj. Manag. 2009, 27, 629-637. [CrossRef]

27. Kog, Y.; Loh, P. Critical success factors for different components of construction projects. J. Constr. Eng. Manag. 2012, 138, 520-528. [CrossRef]

28. Howe, J. Overview of Green Buildings. National Wetlands Newsletter. 2010. Available online: http: / / sallan.org/pdf-docs/CHOWE_GreenBuildLaw.pdf (accessed on 6 August 2015).

29. GhaffarianHoseini, A.; Dahlan, N.D.; Berardi, U.; GhaffarianHoseini, A.; Makaremi, N.; Ghaffarian Hoseini, M. Sustainable energy performances of green buildings: A review of current theories, implementations and challenges. Renew. Sustain. Energy Rev. 2013, 25, 1-17. [CrossRef]

30. Li, D.H.; Yang, L.; Lam, J.C. Zero energy buildings and sustainable development implications-A review. Energy 2013, 54, 1-10. [CrossRef]

31. Radhi, H. Evaluating the potential impact of global warming on the UAE residential buildings-A contribution to reduce the $\mathrm{CO}_{2}$ emissions. Build. Environ. 2009, 44, 2451-2462. [CrossRef]

32. Roonprasang, N.; Namprakai, P.; Pratinthong, N. Experimental studies of a new solar water heater system using a solar water pump. Energy 2008, 33, 639-646. [CrossRef]

33. Chan, A.P.C.; Darko, A.; Ameyaw, E.E. Strategies for promoting green building technologies adoption in the construction industry-An international study. Sustainability 2017, 9, 969. [CrossRef]

34. Qian, Q.K.; Chan, E.H.W.; Khalid, A.G. Challenges in delivering green building projects: Unearthing the transaction costs (TCs). Sustainability 2015, 7, 3615-3636. [CrossRef]

35. Windapo, A.O. Examination of green building drivers in the South African construction industry: Economics versus ecology. Sustainability 2014, 6, 6088-6106. [CrossRef]

36. Bartlett, E.; Howard, N. Informing the decision makers on the cost and value of green building. Build. Res. Inf. 2000, 28, 315-324. [CrossRef]

37. Abdallah, K.B.; Belloumi, M.; De Wolf, D. Indicators for sustainable energy development: A multivariate cointegration and causality analysis from Tunisian road transport sector. Renew. Sustain. Energy Rev. 2013, 25, 34-43. [CrossRef]

38. Chen, Z.; Li, H.; Wong, T.C.C. Environmental management of construction projects in China. J. Constr. Eng. Manag. 2000, 126, 320-324. [CrossRef]

39. Aktas, B.; Ozorhon, B. Green building certification process of existing buildings in developing countries: Cases from Turkey. J. Manag. Eng. 2015, 31, 05015002. [CrossRef]

40. Yang, X.; Zhang, J.; Zhao, X. Factors affecting green residential building development: Social network analysis. Sustainability 2018, 10, 1389. [CrossRef]

41. Shen, W.; Tang, W.; Siripanan, A.; Lei, Z.; Duffield, C.F.; Wilson, D.; Hui, F.K.P.; Wei, Y. Critical success factors in Thailand's green building industry. J. Asian Archit. Build. Eng. 2017, 16, 317-324. [CrossRef]

42. Korkmaz, S.; Swarup, L.; Riley, D. Delivering sustainable, high-performance buildings: Influence of project delivery methods on integration and project outcomes. J. Manag. Eng. 2013, 29, 71-78. [CrossRef]

43. Shen, W.; Tang, W.; Wang, S.; Duffield, C.; Hui, F.; You, R. Enhancing trust-based interface management in international engineering-procurement-construction projects. J. Constr. Eng. Manag. 2017, 143. [CrossRef]

44. Jha, K.N.; Iyer, K.C. Commitment, coordination, competence and the iron triangle. Int. J. Proj. Manag. 2007, 25, 527-540. [CrossRef] 
45. Zhang, L.; Chen, L.; Wu, Z.; Zhang, S.; Song, H. Investigating young consumers' purchasing intention of green housing in China. Sustainability 2018, 10, 1044. [CrossRef]

46. Nunnally, J. Psychometric Theory, 2nd ed.; McGraw-Hill: New York, NY, USA, 1978.

47. Sharma, S. Applied Multivariate Techniques; Wiley: New York, NY, USA, 1996; pp. 116-123.

48. Kaiser, H.F. An index of factorial simplicity. Psychometrika 1974, 39, 31-36. [CrossRef]

49. Wong, P.S.P.; Cheung, S.O. Trust in construction partnering: Views from parties of the partnering dance. Int. J. Proj. Manag. 2004, 22, 437-446. [CrossRef]

50. Berardi, U. Stakeholders' influence on the adoption of energy-saving technologies in Italian homes. Energy Policy 2013, 60, 520-530. [CrossRef]

51. Abair, J.W. Green buildings: When it means to be green and the evolution of green building laws. Urban Lawyer 2008, 40, 623-632.

52. DFDL. Thailand Legal Update: Green Building Energy Standards. 2017. Available online: https://www. dfdl.com/resources/legal-and-tax-updates / thailand-legal-update-green-building-energy-standards-2/ (accessed on 12 August 2018).

53. Stern, P.C. Contributions of psychology to limiting climate change. Am. Psychol. 2011, 66, 303-314. [CrossRef] [PubMed]

54. Anderson, K.; Lee, S.; Menassa, C. Impact of social network type and structure on modeling normative energy use behavior interventions. J. Comput. Civ. Eng. 2013, 28, 30-39. [CrossRef]

55. USGBC. SCG 100th Year Building. 2014. Available online: https://www.usgbc.org/projects/scg-100th-yearbuilding (accessed on 12 August 2018).

56. Albino, V.; Berardi, U. Green buildings and organizational changes in Italian case studies. Bus. Strategy Environ. 2012, 21, 387-400. [CrossRef]

57. Deboonme, A. SCG Offers 'Green' Solutions for Others. 2014. Available online: http://www. nationmultimedia.com/business/SCG-offers-green-solutions-for-others-30234749.html (accessed on 12 August 2018).

58. Asia Green Buildings. Thailand: New SCG Headquarters Held as Example of Green Development. 2016. Available online: http:/ / www.asiagreenbuildings.com/14075/thailand-new-scg-headquarters-heldexample-green-development/ (accessed on 12 August 2018).

(C) 2018 by the authors. Licensee MDPI, Basel, Switzerland. This article is an open access article distributed under the terms and conditions of the Creative Commons Attribution (CC BY) license (http:/ / creativecommons.org/licenses/by/4.0/). 